OPEN ACCESS

Edited by:

Nirupama Darshan Verma University of New South Wales,

Australia

Reviewed by: Soldevila Gloria,

National Autonomous University of

Mexico, Mexico

Giovanna Lombardi, King's College London, United Kingdom

*Correspondence:

Stephen I. Alexander stephen.alexander@ health.nsw.gov.au

Specialty section: This article was submitted to T Cell Biology, a section of the journal Frontiers in Immunology

Received: 31 May 2021 Accepted: 05 August 2021 Published: 26 August 2021

Citation:

Hu M, Rogers NM, Li J Zhang GY, Wang YM, Shaw K, O'Connell PJ and Alexander SI (2021) Antigen Specific Regulatory $T$ Cells in Kidney Transplantation and Other Tolerance Settings.

Front. Immunol. 12:717594. doi: 10.3389/fimmu.2021.717594

\section{Antigen Specific Regulatory T Cells in Kidney Transplantation and Other Tolerance Settings}

\author{
Min $\mathrm{Hu}^{1,2}$, Natasha M. Rogers ${ }^{1}$, Jennifer $\mathrm{Li}^{1}$, Geoff Y. Zhang ${ }^{3}$, Yuan Min Wang ${ }^{3}$, \\ Karli Shaw ${ }^{3}$, Philip J. O'Connell ${ }^{1}$ and Stephen I. Alexander ${ }^{3 *}$ \\ ${ }^{1}$ Centre for Transplant and Renal Research, Westmead Institute for Medical Research, Sydney, NSW, Australia, ${ }^{2}$ Faculty of \\ Medicine and Health, The University of Sydney, Sydney, NSW, Australia, ${ }^{3}$ Centre for Kidney Research, Children's Hospital at \\ Westmead, Sydney, NSW, Australia
}

Kidney transplantation is the most common solid organ transplant and the best current therapy for end-stage kidney failure. However, with standard immunosuppression, most transplants develop chronic dysfunction or fail, much of which is due to chronic immune injury. Tregs are a subset of $\mathrm{T}$ cells involved in limiting immune activation and preventing autoimmune disease. These cells offer the potential to provide tolerance or to allow reduction in immunosuppression in kidney transplants. The importance of Tregs in kidney transplantation has been shown in a number of seminal mouse and animal studies, including those with $T$ cell receptors (TCRs) transgenic Tregs (TCR-Tregs) or Chimeric Antigen Receptor (CAR) Tregs (CAR-Tregs) showing that specificity increases the potency of Treg function. Here we outline the animal and human studies and clinical trials directed at using Tregs in kidney transplantation and other tolerance settings and the various modifications to enhance allo-specific Treg function in vivo and in vitro.

Keywords: kidney, transplantation, Treg, antigen, tolerance

\section{INTRODUCTION}

Kidney transplantation is currently the preferred treatment for patients with end-stage kidney disease (ESKD). The primary limitation of long-term kidney allograft survival has been chronic immune-mediated rejection. This is due to both cellular and humoral pathways as well as innate immune factors and possibly other pathways. Major improvements have occurred over time with improved and more specific immune suppression particularly targeting $\mathrm{T}$ effector cells. However, because of the deleterious effects of immunosuppression a major goal has been to achieve immune tolerance to the transplant.

In organ transplantation, there has been a longstanding interest in transferring therapies that create tolerance to the clinic (1). In kidney transplantation, a number of bone marrow-based strategies creating temporary or permanent donor hematopoietic chimerism have reached clinical trials. The first of these was done at Massachusetts General Hospital (MGH), followed closely by Stanford, John Hopkins and North Western (2-6).

Regulatory $\mathrm{T}$ cells (Tregs) are a subset of $\mathrm{T}$ cells that suppress immune activation and limit autoimmunity in the periphery (7). A number of cell types with immune-regulatory function have been characterized as Tregs, though the one best understood, at present, are the $\mathrm{CD} 4^{+} \mathrm{FOXP} 3^{+}$ 
Tregs. These either arise in the thymus (tTregs) or develop from peripheral $\mathrm{CD}^{+}{ }^{+} \mathrm{T}$ cells that convert into $\mathrm{CD}^{+}{ }^{+} \mathrm{FOXP} 3^{+}$Tregs as peripherally derived Tregs (pTregs) (8). Previously, it had been thought that peripheral tolerance due either tTregs or pTregs would be insufficient for long standing tolerance. However increasing understanding of Tregs and other regulatory subsets has led to the possibility that transplant tolerance allowing reduction or cessation of immunosuppression could be achieved using regulatory cell subsets (9).

We and others have shown a role for Tregs in 1) protecting against autoimmune kidney disease, 2) maintaining tolerant kidney grafts, 3) preventing human islet allograft and pig xenograft rejection in humanised mouse models, and 4) preventing kidney allograft loss in mouse models of kidney tolerance (10-13). In addition to our studies, there have been 3 bone marrow transplant (BMT) trials reporting the use of Tregs in graft versus host disease (GVHD), and there are current human trials using Tregs in autoimmune diabetes at UCSF (14-17). Clinically, polyclonal human Tregs have been shown to be safe to infuse in kidney transplant patients in the multicentre One Study (18) and the safety of this study suggests that Tregs may be the next frontier of cell therapy (19-21). This has also been achieved at North Western University in kidney transplant recipients with ex-vivo expanded Tregs (22). This group has also developed protocols for ex-vivo expanded alloantigen specific Tregs (23).

In this review, we focus primarily on antigen specific Tregs induction in kidney transplantation tolerance and other tolerance studies in animal models and human studies of kidney transplantation and discuss several approaches to generate and expand antigen specific Tregs which can protect against transplant rejection.

\section{REGULATORY T CELLS}

Tregs that limit autoimmunity have been studied for a long time. Almost 20 years ago the identification of a $\mathrm{CD} 4{ }^{+} \mathrm{CD} 25^{+}$subset as necessary to protect against autoimmunity and limit alloresponse and the subsequent identification of Foxp3 as a master transcription factor identified this regulatory subset (24-27). Further, the separation of these FOXP3 ${ }^{+}$Tregs into tTregs or pTregs developed in the periphery in vivo has helped shape an understanding of their action (28). Tregs can function through multiple pathways to induce tolerance. Tregs are likely to have a number of functional subsets that mirror effector T cells (28). Naïve $\mathrm{CD}^{+} \mathrm{T}$ cells can be induced into FOXP3 ${ }^{+}$Tregs in vitro as iTreg in this review. tTregs with epigenetic changes, provide stability of demethylated FOXP3 especially at the Treg-specific demethylated region (TSDR) site, making them are more resistant to conversion to other CD4 T cell phenotypes (29); pTregs and iTregs without TSDR demethylation, appear at risk of conversion into pathogenic subsets of CD4 T cells, including Th17 (30).Many subsets of effector Tregs express lineage-specific transcription factors in combination with the transcription factor B-lymphocyte-induced maturation protein 1 (BLIMP1) which acts as a repressor. The important role of IL-2 and IL-4 in driving alloantigen specific Tregs in transplantation has recently been demonstrated (31). It has also been shown that acquisition of antigen-specific memory by Tregs is associated with more potent function (32). Further recent data suggests that memory Tregs are more potent than naïve Tregs as shown in antigen-specific models of skin inflammation where response to self-antigen imprints regulatory memory in skin tissues and this has also been shown in rat cardiac transplant models (33). Of interest, antigen-specific $\mathrm{CD}^{+}$type 1 regulatory T cells that express IL-10 and/or TGF- $\beta$ (Tr1) can be induced independently of foxp3 expression, can limit antigen-specific immune responses and may also be important as mediators of transplant tolerance (34, 35). Further identification of memory markers on effector Tregs in transplant settings suggests these may be more potent (36).

\section{DONOR ANTIGEN-SPECIFIC TREGS IN ANIMAL TRANSPLANT MODELS}

In transplantation, the key goal is to achieve donor-specific transplant tolerance in which the donor allograft is accepted without long-term immunosuppressive requirements, and the recipient remains capable of responding to pathogenic microorganisms and other alloantigens (37). Donor-specific tolerance of allografts arises spontaneously in various animal models $(11,38-40)$ and has been well-documented in various transplant populations (Figure 1), including our study in a pediatric liver transplant recipient with full hematopoietic chimerism (41). As well as Treg therapy, several approaches have been used to achieve transplant tolerance in animal models, including costimulatory blockade, hematopoietic donor chimerism using BMT and stem cell transplantation, targeting of effector cell activation and recruitment, and donor-specific transfusions (DST). Among these approaches, donor-antigen specific Foxp $3^{+}$Tregs have been found to play the crucial role in the maintenance of allograft tolerance in several transplant animal models.

\section{Donor Antigen-Specific Tregs in Spontaneous Acceptance of Kidney Allografts}

Donor-specific tolerance of renal allografts occurring spontaneously across certain MHC mismatched mouse strains is a valuable model for studying transplant tolerance $(11,38-40)$. Studies showed spontaneous kidney allografts tolerance occurred in the DBA/2 $\left(\mathrm{H} 2^{\mathrm{d}}\right)$ to $\mathrm{C} 57 \mathrm{BL} / 6\left(\mathrm{H} 2^{\mathrm{b}}\right)$ transplant model and was associated with $\mathrm{T}$ cell mediated immune regulation requiring TGF- $\beta$ (40). In a spontaneous kidney allograft tolerance mouse model with C57BL/6 mice as donors and B10.BR $\left(\mathrm{H} 2^{\mathrm{k}}\right)$ as recipients, we found $\mathrm{Foxp}^{+}$ Tregs increased in tolerant kidney allografts (39). Further we and others demonstrated that Foxp $3^{+}$Tregs were essential for tolerance induction in spontaneously accepted kidney allograft from DBA/2 to $\mathrm{C} 57 \mathrm{BL} / 6$ mice, where depletion of $\mathrm{CD} 4^{+} \mathrm{CD} 25^{+}$Tregs or Foxp ${ }^{+}$ Tregs abolished kidney allograft tolerance $(11,42)$. Using DEREG mice $(\mathrm{C} 57 \mathrm{BL} / 6)$ that carry the diphtheria toxin receptor and 


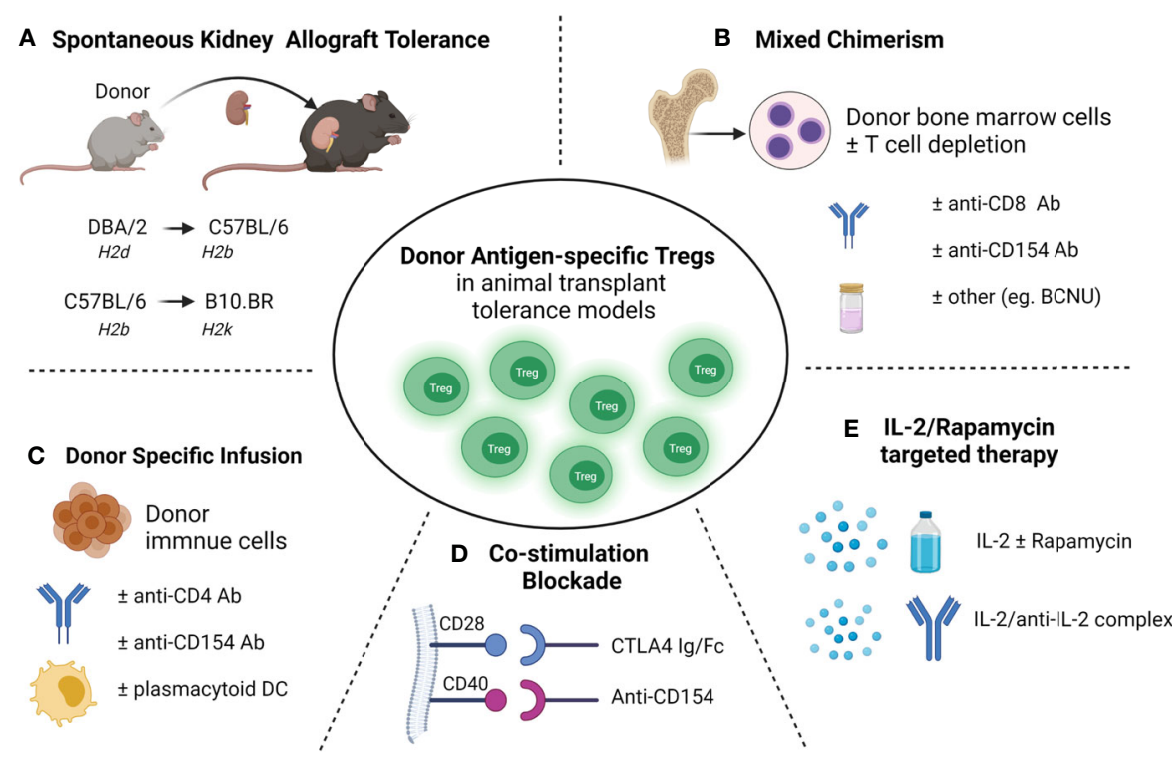

FIGURE 1 | Donor antigen-specific Tregs developed in transplant tolerance mouse models (A) Spontaneous acceptance of kidney allotransplant tolerance. (B) Mixed chimerism induced allo-transplantation tolerance via bone marrow transplantation. (C) Donor-specific transfusions (DST) induced allotransplantation tolerance. (D) Blockade of the B7-CD28 (using CTLA-4 Ig/Fc) or/and CD40-CD40L (using anti-CD154 mAb) co-stimulatory pathway induced transplantation tolerance; (E) and IL-2 and rapamycin targeted therapies induced transplantation tolerance.

enhanced green fluorescent protein (DTR-eGFP) transgene under control of the Foxp3 promoter, we identified donor -antigenspecific Foxp $3^{+}$Tregs that were developed in DBA/2 kidney allografts in $\mathrm{C} 57 \mathrm{BL} / 6$ recipient mice and confirmed dominant and donor antigen specificity of kidney allograft Tregs in vivo in Rag-/- mice (11). These donor antigen-specific Foxp $3^{+}$Tregs expressed elevated levels of TGF- $\beta$, IL-10, interferon gamma (IFN- $\gamma$ ), BLIMP1 and the chemokine receptor 3 (Cxcr3) (11). These studies demonstrated the crucial role of Foxp $3^{+}$Tregs in transplant tolerance and the therapeutic potential of donor antigenspecific Tregs in clinical settings to improve transplant outcomes.

\section{Donor Antigen-Specific Tregs in Allo-Transplantation With DST}

In transplantation, Tregs have been shown to develop in the recipients after DST and the critical role of Tregs has been reported in DST models with mismatch at both major histocompatibility class (MHC) class I and class II (43-48). However, other studies reported equal expansion of recipient transplant-specific Tregs in the rejecting and tolerant heart allografts induced through DST combined with anti-CD154 mAb, and without Treg expansion in the spleen (49). Although DST combined with cyclophosphamide treatment failed to prolong $\mathrm{BALB} / \mathrm{c}\left(\mathrm{H} 2^{\mathrm{d}}\right)$ islet allograft survival in C57BL/6 $\left(\mathrm{H} 2^{\mathrm{b}}\right)$ host mice, additional infusion of either donor-reactive Tregs $\left(5 \times 10^{6}\right)$ or polyclonal Tregs $\left(25 \times 10^{6}\right)$ led to prolonged survival of allogeneic islets in $>70 \%$ of $\mathrm{C} 57 \mathrm{BL} / 6$ host demonstrating the critical role of Tregs in DST for induction of tolerance (46). Other studies have also reported DST combined with anti-CD154 mAb and plasmacytoid dendritic cells (pDCs) induced BALB/c heart allograft tolerance in
C57BL/6 hosts in which Tregs developed and expanded in the lymph node (47). In a MHC-mismatched skin allotransplant mouse model, mice pre-treated with anti-CD4 monoclonal antibody $(\mathrm{mAb})$ and DST achieved dominant tolerance which was mediated by Tregs in a CTLA-4 and IL-10-dependent manner. However $\mathrm{CD}^{+} \mathrm{CD} 25^{+}$Tregs from graft tolerant mice had no demonstrable specificity for the tolerizing donor antigens (50). In models using DST with additional immunological manipulation, expanded alloreactive Tregs occurred predominantly through the direct pathway of allorecognition (51) and long-term graft acceptance predominantly relied on indirectly activated Tregs (45, 52). Interestingly, in a single MHC-I mismatch skin transplant model, we demonstrated dominant F1 skin-allograft [C57BL/6.C $\left.\left(\mathrm{H}-2^{\mathrm{bm} 1}\right) \times \mathrm{C} 57 \mathrm{BL} / 6\left(\mathrm{H} 2^{\mathrm{b}}\right)\right]$ tolerance induced by a single DST across an unmanipulated C57BL/6 host (53). In this model, expansion of antigen-specific Foxp $3^{+}$Tregs in F1 grafts and spleens of recipient mice were due to thymus-derived Foxp $3^{+}$ Treg proliferation that were indirectly activated. The essential role of Foxp $3^{+}$Tregs in this model was confirmed by depletion of Foxp $3^{+}$Tregs in DEREG mice which abrogated F1 skin graft tolerance (53).

\section{Donor Antigen-Specific Tolerance in Allo-Transplantation Combined With BMT}

Kidney transplant tolerance in a clinical setting has been achieved with non-myeloablative BMT to induce hematopoietic mixed chimerism, but is limited by the risk of GVHD, and loss of both mixed chimerism and tolerance $(3,54,55)$. Mixed chimerism achieves transplant tolerance through both central and peripheral depletion of alloreactive cells (54). More recent data support an 
important role for Tregs in mixed chimerism, both in limiting GVHD and maintaining chimerism with host Treg cells involved in preventing chronic allograft rejection and donor Treg cells controlling GVHD in animal models and transplant recipients (56-61). Mouse studies have shown an important role for host Treg cells in tolerance using nonmyeloablative BMT, costimulatory blockade and total body irradiation to achieve mixed chimerism across a full MHC mismatch (58). Mixed chimerism only occurred in the presence of host Tregs in host mice and allogeneic T cell-depleted BMT in a non-lymphoablative irradiation regimen (57). Moreover, host Tregs specific for directly presented donor antigens prevented acute rejection only of skin and heart allografts, while host Tregs specific for both directly and indirectly presented alloantigens prevented both acute and chronic rejection in the same models (57). Using a non irradiation regimen in which the host received, anti-CD154 mAb, a single dose of depleting CD8 mAb, N,N-bis(2-chloroethyl)-nitrosourea (BCNU, an alkylating agent), and allogeneic BMT from methyl-guaninemethyl-transferase (MGMT) transgenic mice, high levels of donor mixed chimerism without GVHD were achieved across fully MHC mismatched mice leading to donor-specific skin allograft tolerance (56). MGMT is a DNA repair enzyme that removes BCNU from guanine and limits BCNU toxicity, enhancing engraftment of donor hematopoietic cells. Importantly, both donor and host Foxp $3^{+}$Tregs were expanded in this model, suggesting their important role for the maintenance of tolerance in mixed chimerism (56). In non-human primates (NHPs) where kidney allograft tolerance was achieved with the development of transient mixed chimerism using T cell-depleted BMT and costimulatory blockade without myeloablation, Foxp $3^{+}$Tregs were found to be enhanced in tolerant recipients (62). Thus, mixed chimerism and Tregs are likely to be synergistic in achieving transplant tolerance and limiting GVHD in clinical transplantation (63-65).

\section{Donor Antigen-Specific Tregs in Costimulation Blockade-Induced Transplant Tolerance}

In several transplant model systems, blockade of the B7-CD28 (using CTLA-4 Ig/Fc) or CD40-CD40L (using anti-CD154 mAb) co-stimulatory pathway induced donor graft tolerance (66-72). The impact of Treg numbers and functionality on the efficacy of costimulation blockade, and the requirement of Tregs in transplant induction via co-stimulation blockade is an area of active investigation $(67,68,73,74)$. Although CTLA-4-Ig treatment in C57BL/6 naïve mice causes a decrease in Treg and Helios ${ }^{+}$Foxp $^{+}$Tregs, it prolongs fully mismatched BALB/c heart allograft survival in $\mathrm{C} 57 \mathrm{BL} / 6$ recipients. However, it does not protect single MHC-II mismatched heart allografts in C57BL/6 recipients in which long-term allograft survival was Tregs dependent (73). In a different model, treatment with CTLA4-Ig abolished skin allograft tolerance induced by IL-2/ anti-IL-2 complex suggesting that allo-Treg development requires costimulation (75). Others reported that in the presence of $\mathrm{B} 7: \mathrm{CD} 28$ and CD40:CD40L co-stimulatory blockade, the suppressive function of $\mathrm{CD} 4{ }^{+} \mathrm{CD} 25^{+}$Tregs was activated, suppressing the proliferation of $\mathrm{CD}^{+}$effector cells (67). Experiments in vitro by Vogel et al. found that co- stimulatory blockade primed Foxp ${ }^{+}$Tregs to be more suppressive than naïve Foxp $3^{+}$Tregs (76). Depletion of $\mathrm{CD} 4^{+} \mathrm{CD} 25^{+}$Tregs in recipient mice abolished heart allograft tolerance induced by CD154 mAb treatment (77). In an islet xenotransplant pig-mouse model, we found expanded Foxp $3^{+}$ Tregs populations in the xenograft, spleen and draining lymph nodes that were induced by treatment with CTLA- 4 Fc and antiCD154 mAb. Once again activated Foxp $3^{+}$Tregs had more potent regulatory function in vivo than naive Tregs (68). Further, depletion of Foxp $3^{+}$Tregs at induction (unpublished) or maintenance (68) in recipient mice with the blockade of B7CD28 or CD40-CD40L abolished transplant tolerance thereby confirming the essential role of these cells. However, antigen specificity of Treg after the induction of tolerance does not appear to be universal. Using a combination of nondepleting CD4, CD8, and CD154 mAb to induce fully mismatched C57BL/ $10\left(\mathrm{~B} 10, \mathrm{H}-2^{\mathrm{b}}\right)$ skin allograft tolerance in $\mathrm{CBA}\left(\mathrm{H} 2^{\mathrm{k}}\right)$ mice, antigen specific tolerance to the second skin allograft was shown to be mediated by $\mathrm{CD} 4{ }^{+} \mathrm{CD} 25^{+}$Tregs; but these Tregs from tolerant mice had no demonstrable donor antigen specificity after adoptive transfer (78).

\section{Donor Antigen-Specific Tregs in IL-2 and Rapamycin Targeted Therapies}

The cytokine interleukin-2 (IL2) is a key regulator of immune cells including Tregs that constitutively express the high-affinity IL-2R $\alpha$ (CD25) and are highly sensitive to very low doses of IL-2 (79-81). In the clinic, low-dose IL-2 therapy has been shown to selectively expand FOXP3 Tregs and used successfully to treat chronic GVHD (82), hepatitis C virus-induced vasculitis (83), systemic lupus erythematosus (SLE) (84), and type 1 diabetes (85, 86). In a humanized mouse model, we demonstrated that the infusion of in vitro-expanded human $\mathrm{FOXP}^{+}$Tregs in the presence of IL-2 and rapamycin prevented porcine neonatal islet cell cluster xenograft rejection (87). Low dose IL- 2 treatment in the host mice led to expansion of Foxp $3^{+}$Tregs in vivo and prolonged allograft survival in a full MHC-mismatch corneal transplant model of $\mathrm{C} 57 \mathrm{BL} / 6$ grafts to $\mathrm{BALB} / \mathrm{c}$ hosts, and these in vivo expanded Tregs also demonstrated donor antigen specificity (88). Further, IL-2 treatment of host mice preferentially expanded infused donor antigen-specific Tregs generated in vitro, and improved the skin allograft survival in a single MHC-mismatch mouse model (89). Using IL-2/anti-IL-2 antibody complexes has also been shown to induce Foxp $3^{+}$Tregs expansion, prolong islet allograft survival (90) and protect against proteinuric chronic kidney disease (91). In our study, low dose of IL-2 treatment alone failed to prolong islet allograft survival in humanized mice despite expandingFOXP3 ${ }^{+}$Tregs in vivo (92). Graft survival depended on the balance of effector $\mathrm{T}$ cells and Tregs. Rapamycin has been shown to be pro-tolerogenic by allowing expansion of human and mouse Tregs while also suppressing $\mathrm{CD}^{+} \mathrm{T}$ effector cells in experimental studies (93-96). Whilst lowdose rapamycin treatment did not lead to either Treg expansion in vivo or prolongation of islet graft survival in humanized mice, the combination of IL-2 and rapamycin led to an expansion of Tregs and prolonged human islet allograft survival in this humanized mice model (92). The combination of IL-2 and rapamycin has also 
been reported to prolong skin graft survival in minor antigen mismatch and semi-allogeneic mouse recipients (97). These studies suggest a combination of agents that selectively expand Tregs in vivo whilst limiting effector T-cell expansion will be required to protect graft rejection if these therapies are to be translated in the clinic. Although these results in rodent studies are encouraging, more work needs to be done to ensure that $\mathrm{T}$ cell activation in vivo is limited to the Treg population only. IL-2, at the appropriate dose, can activate effector T cells, and a clinical trial of low dose IL-2 in liver transplant recipients had to be ceased due to increased rejection without evidence of Treg induced suppression (NCT02949492).

\section{POTENTIAL METHODS TO GENERATE AND INDUCE ALLOSPECIFIC TREGS EX VIVO}

Concerns around non-specific immune suppression and the need to increase potency has led to the development of antigen-specific Tregs which display more efficient suppressive function than naïve Tregs. There are several methods to generate donor antigenspecific Tregs from $\mathrm{FOXP}^{+}{ }^{+}$Tregs $\left(\mathrm{CD} 4^{+} \mathrm{CD} 25^{+} \mathrm{CD} 127^{-}\right)$ precursors, and antigen-specific iTregs or $\operatorname{Tr} 1$ from naïve $\mathrm{CD} 4^{+}$ T cells for therapy in transplantation (Figure 2) $(98,99)$.

\section{Direct Antigen Expansion With Donor HLA Expressed by APC}

Human Tregs expanded in the presence of donor antigen ex vivo demonstrate enhanced suppressive function and were more effective for protecting skin allograft rejection in a humanized mouse model (100). Our group has identified xenospecific human $\mathrm{CD}_{2} 7^{+} \mathrm{HLADR}^{+}$Tregs generated in the presence of pig donor peripheral blood mononuclear cells (PBMCs) in a mixed lymphocyte reactions (MLR) system which demonstrated more effective protection of pig islet xenograft rejection in a humanized mouse model (unpublished). Allospecific Tregs were generated using isolated $\mathrm{CD} 4^{+} \mathrm{CD} 25^{+} \mathrm{CD} 127^{-}$Tregs from PBMCs of healthy volunteers in the presence of soluble 4-trimer CD40 ligand (CD40L)-activated donor B cells (23) or skinderived myeloid DCs (101). Further studies have shown that human allospecific Tregs can be generated in a MLR system from PBMC of uremic patients in the presence of donor PBMCs under conditions of costimulatory blockade with belatacept (102). Allospecific Tregs were generated in different MLR system in which sorted $\mathrm{CD} 4^{+} \mathrm{CD} 25^{+} \mathrm{CD} 127^{-}$Tregs from transplant recipient' $\mathrm{PMBCs}$ were expanded with donor $\mathrm{B}$ cells activated using K562 cells and expressing human CD40L (100). These allospecific Tregs maintained high levels of FOXP3 expression and TSDR $(100,102)$, and demonstrated safety for cell therapy in clinical kidney transplant trials $(18,100,102)$.

\section{Indirect Antigen Expansion With Donor HLA Fragments Presented by Host APC/MHC}

Another approach has been the use of indirectly presented HLA molecules in the context of recipient MHC using antigen presenting cells (dendritic cells or B cells) pulsed with donor antigen. This may potentially be more effective for suppression of chronic rejection (103). However, this is often limited by the small clone size of TCR recognizing the peptide in the context of

\section{A}

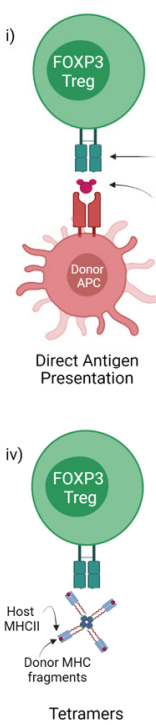

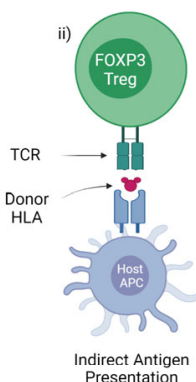

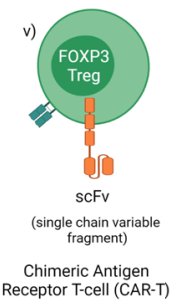

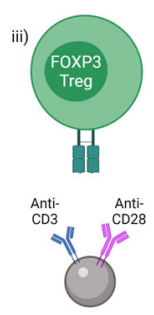

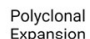

Expansion
Beads

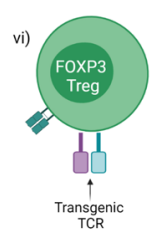

Transgenic
B
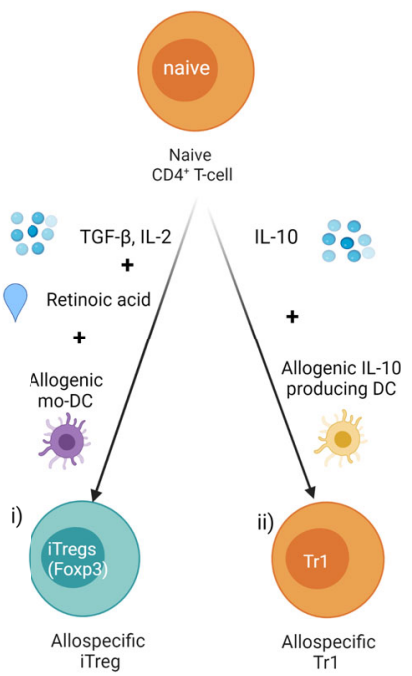

FIGURE 2 | Methods of allospecific Treg derivation (A) Generating donor antigen-specific Tregs from FOXP3 ${ }^{+}$Tregs (CD4 $\left.4^{+} \mathrm{CD} 25^{+} \mathrm{CD} 127^{-}\right)$precursors. This includes donor HLA presented to generate i) direct antigen expanded (donor APC/MHCll) or ii) indirect antigen expanded Tregs ed (host APC/MHCll). iii) Polyclonal expansion with antiCD3/CD28 beads. iv) Isolation of specific Tregs using Tetramers composed of host class II MHC \& donor MHC fragments. v) Insertion of antibody fragment scFv connected to TCR to create a CAR. vi) Genetic modification of Tregs with transgenic TCR. (B) Inducing donor antigen-specific i) iTreg and ii) $\operatorname{Tr}^{1}$ from naïve CD4 ${ }^{+}$T cells. 
self-MHC or the development of inhibitory constimulatory molecules by the APC.

\section{Isolation of Specific Tregs Using Tetramers Composed of Host Class II MHC \& Donor MHC Fragments}

This has the advantage of having a broad range of $\mathrm{T}$ cell receptors (TCRs) in the selected population. It still requires Treg expansion and sorting. It also has issues around the initial selection of Tregs and it may potentially be useful in displaying a range of targets. However MHC Class II tetramers have proved less efficient than Class I and may be a barrier to larger scale clinical use (104).

\section{Insertion of Allospecific TCR}

The use of TCRs against an alloantigen was first used by Simpson and her group using TCR transgenic mice against the $\mathrm{H}-\mathrm{Y}$ antigen (105, 106). Here Tregs directed against $\mathrm{H}-\mathrm{Y}$ could induce tolerance against a minor antigen $(107,108)$. TCR-transduced Tregs specific for allogeneic MHC class II molecules induced long-term survival of partially MHC-mismatched heart grafts when combined with shortterm adjunctive immunosuppression (109). This demonstrated the capacity and increased potency of TCR targeted Treg therapy. More recently this approach has been used in cancer against minor H-A antigens but may have a future role in transplantation tolerance (110).

\section{Car-Tregs}

Antibody fragment scFv connected to the intracytoplasmic tail of the TCR and associated signaling molecules are transduced into Tregs to create a chimeric antigen receptor (CAR) Treg (111). The targeting of Tregs in organ transplantation and in autoimmunity to the transplanted cells or autoimmune tissues is an attractive option. The potency of antigen targeting was first shown by the Simpson group as described above. T cell specificity has also been achieved using antibody fragments linked to intracellular TCR signalling domains called CARs. CAR $\mathrm{T}$ cells have been used most impressively in the treatment of CD19 lymphoma using CD8 T cells engineered with a scFv chain from an antibody against $\mathrm{CD} 19$ fused to the intracellular component of the $\mathrm{T}$ cell receptor (112-114). These hybrid receptors are comprised of a $\mathrm{scFv}$ derived from monoclonal antibodies or an antigen-binding fragment (Fab) fused to $\mathrm{CD} 3-\zeta$ transmembrane and end domains, the intracellular functional component of the TCR. This approach has been used to direct $\mathrm{T}$ cells against cancer antigens, most spectacularly against CD19. Further modifications enhance the survival and activity of the Treg and drive the functionality of the $\mathrm{T}$ cells have been undertaken (115).

The efficacy of CAR Tregs directed against alloantigens has been demonstrated using HLA-A2 specific CAR $\mathrm{T}$ cells in vitro and in transplant models (116-118). However, CAR Tregs while limiting skin graft rejection in naïve mice cannot prevent skin graft rejection in sensitized mice (119). Many strategies exist to improve the isolation and expansion of Tregs and subsequent genetic modifications to alter cytokine signalling, enhance regulatory elements or inhibit signals that supress regulation and develop pathways for testing in large animals and human trials (120).

\section{Generating Allospecific iTregs From Naïve CD4 $^{+}$T Cells}

iTregs are induced to express FOXP3 from naïve $\mathrm{CD} 4^{+}$under specific condition in vitro, but iTregs without TSDR demethylation, appear more susceptible to conversion into pathogenic subsets of $\mathrm{CD}^{+} \mathrm{T}$ cells (30). iTregs induced with TGF- $\beta$ in the presence of all-trans retinoic acid (ATRA) and rapamycin demonstrated robust suppressive function in vitro but not in vivo, in the humanized GVHD mouse model (121). Interestingly, allospecific iTregs that were induced with TGF- $\beta 1$, IL-2, and ATRA in the presence of allogeneic monocyte-derived dendritic cells, can specifically suppress donor allo-responses but not third-party allo-responses, and maintain suppressive function in the presence of pro-inflammatory cytokines, despite methylation of the FOXP3 TSDR (122).

\section{Generating Allospecific Tr1}

Tr1 cell therapy in GVHD trials including NCT03198234 suggested therapeutic possibility in the treatment of transplantation rejection (123). Allospecific $\operatorname{Tr} 1$ were enriched in cultured $\mathrm{CD}^{+} \mathrm{T}$ cells that were stimulated with allogeneic IL-10-producing DCs generated from $\mathrm{CD} 14^{+}$monocytes in the presence of IL-10 (124). These allospecific Tr1 showed specific suppression function to donor alloresponse in vitro and maintained a tolerogenic gene expression profile in vivo (124).

\section{ANTIGEN-SPECIFIC TREGS IN TRANSPLANT CLINICAL TRIALS}

Given the central role of T-cells in downstream effector function, Tregs have been studied as a potential therapeutic in human solid organ transplantation. Sixteen Treg clinical trials that have focused on feasibility, safety and preliminary efficacy of infused Tregs to reduce the dose of calcineurin inhibitor (CNI)-based immunosuppression have been reported. However, the majority of reported clinical trials using Tregs lack the capacity to robustly identify mechanistic effects and much of our understanding of underlying mechanisms relies on extrapolation of results from rodent and non-human primate studies.

Autologous or donor-derived peripheral blood is the most common source of Tregs used in clinical trials, although alternate sources such as umbilical cord blood and paediatric thymus, non-lymphoid tissue such as skin, adipose tissue and muscle have been explored (125) (Figure 3). Peripheral blood contains only a small proportion of Tregs that require purification via $\mathrm{CD} 25^{+}$cell selection, with or without $\mathrm{CD} 8^{+}$depletion. Ex vivo expansion of these naturally-occurring Tregs can be achieved through various means, but the choices are dependent on whether polyclonal or donor alloAg-reactive Treg (darTreg) are required (100). darTregs are theoretically more potent, however the majority of trials have expanded polyclonal Tregs with a combination of IL-2 and anti-CD3/CD28 magnetic bead stimulation \pm rapamycin or TGF- $\beta$, although this process may require a greater cell infusion dose to achieve donor-specific suppressive effects (126-129) (Figure 3). 


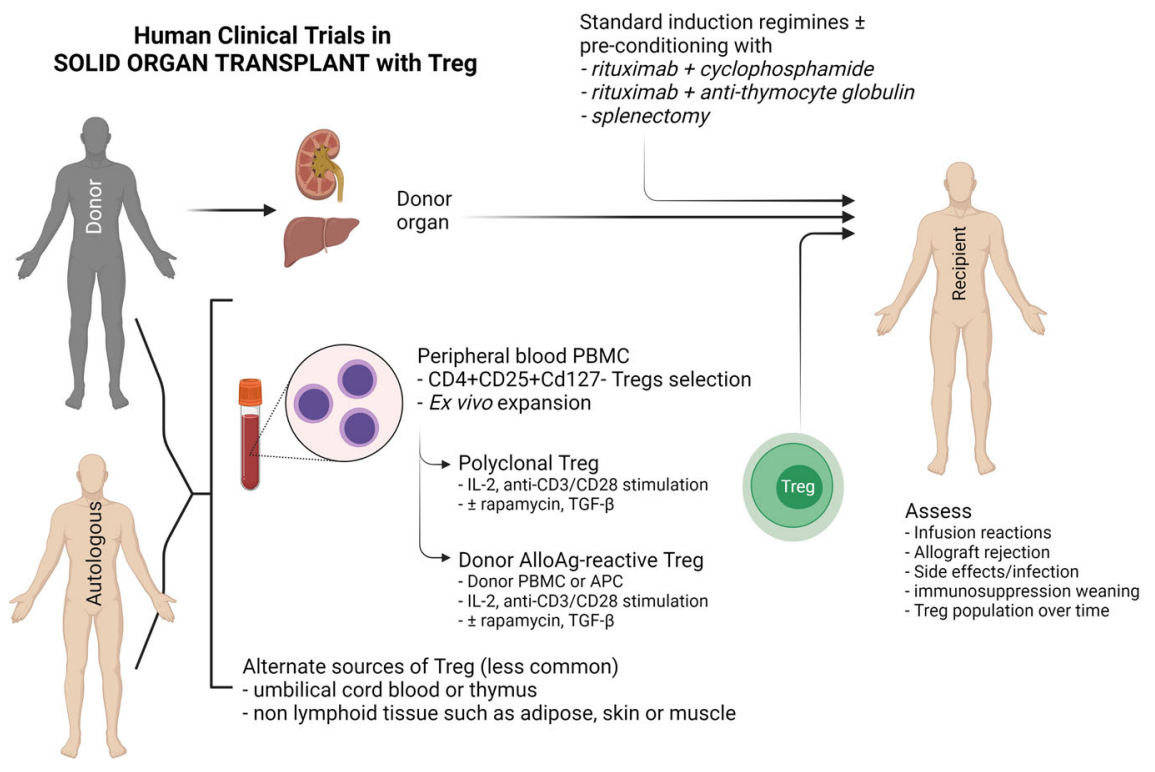

FIGURE 3 | Schematic diagram of current clinical Treg trials in kidney and liver transplantation. This diagram indicates the sources of FOXP3 ${ }^{+}$Tregs $\left(\mathrm{CD} 4^{+} \mathrm{CD} 25^{+} \mathrm{CD} 127^{-}\right)$, the two main methods of Treg expansion and assessment in clinical trials.

Clinical studies in kidney or liver transplantation have demonstrated Treg safety in early phase I/II studies. The One study (18), which included polyclonal Treg $(\mathrm{n}=12$ and 11 at Guy's and Oxford University Hospitals, UK and Charite Hospital, Germany) and darTregs $(\mathrm{n}=2)$ at the University of California San Francisco Medical Centre and $(\mathrm{n}=3)$ at Massachusetts General Hospital, USA, did not demonstrate significant adverse events such as rejection. However, infusion of darTregs following a preconditioning regimen of splenectomy, rituximab with cyclophosphamide, or rituximab with rabbit anti-thymocyte globulin in living donor kidney transplantation resulted in significant rejection risk following immunosuppressive drug weaning (130). This highlights the caution required to achieve in vivo translation of cell therapies - despite demonstrating functionally suppressive Tregs in vitro, there was either insufficient Treg dosage, loss of regulatory function in vivo, or significant depletion of recipient Tregs. Additional studies of darTregs in liver transplantation (deLTa, NCT02188719) was not completed within the study timeframe, and several additional studies (ThRIL, NCT02166177; ARTEMIS NCT02474199) are either not formally reported or yet to commence recruiting (LITTMUS, NCT03654040). Tr1 cell therapy in two kidney transplant patients in the One Study group showed $\operatorname{Tr} 1$ cells expand and Tr1-cell tolerogenic gene expression profile remains stable even under active immunosuppressive treatment (124).

\section{CONCLUSIONS}

The safety of infusing mildly manipulated Tregs has been demonstrated in clinical trials of kidney transplantation.
Promising animal studies suggest that specific Tregs or modified Tregs may be more potent and allow further reduction in immunosuppression or true tolerance. There are caveats with CAR $\mathrm{T}$ cells failing to suppress rejection in sensitized mice and primate studies demonstrating Treg conversion. However overall, the accumulating evidence suggests that these barriers can be overcome and allo-specific Tregs therapy translated into the clinical practice.

\section{AUTHOR CONTRIBUTIONS}

$\mathrm{MH}$ drafted the sections of donor antigen specific Tregs in animal transplant models, revised and edited the paper. NR drafted the section of antigen specific Tregs in transplantation clinical trials, revised and edited the paper. JL drafted the figure and edited the the paper. GZ, YW, and KS revised the draft. PO'C revised the draft and edited the paper. SA drafted the sections of introduction, potential methods to induce allospecific Tregs $e x$ vivo, and conclusions, edited and finalized the paper. All authors contributed to the article and approved the submitted version.

\section{FUNDING}

This work was supported by the National Health and Medical Research Council of Australia (NHMRC) grants, JDRF/ Australian Research Council, and University of Sydney. MH was awarded an early career fellowship from the NHMRC (GNT1013185), a Deputy Vice Chancellor University of Sydney research fellowship (IRMA178768). NR is a recipient 
ofan NHMRC career development fellowship (GNT1158597). PO'C was a recipient of a senior practitioner fellowship from the NMHRC (GNT1125456) and the principal investigator

\section{REFERENCES}

1. Nankivell BJ, Alexander SI. Rejection of the Kidney Allograft. N Engl J Med (2010) 363(15):1451-62. doi: 10.1056/NEJMra0902927

2. Spitzer TR, Delmonico F, Tolkoff-Rubin N, McAfee S, Sackstein R, Saidman S, et al. Combined Histocompatibility Leukocyte Antigen-Matched Donor Bone Marrow and Renal Transplantation for Multiple Myeloma With End Stage Renal Disease: The Induction of Allograft Tolerance Through Mixed Lymphohematopoietic Chimerism. Transplantation (1999) 68(4):480-4. doi: 10.1097/00007890-199908270-00006

3. Kawai T, Cosimi AB, Spitzer TR, Tolkoff-Rubin N, Suthanthiran M, Saidman SL, et al. HLA-Mismatched Renal Transplantation Without Maintenance Immunosuppression. N Engl J Med (2008) 358(4):353-61. doi: 10.1056/NEJMoa071074

4. Luznik L, O’Donnell PV, Symons HJ, Chen AR, Leffell MS, Zahurak M, et al. HLA-Haploidentical Bone Marrow Transplantation for Hematologic Malignancies Using Nonmyeloablative Conditioning and High-Dose, Posttransplantation Cyclophosphamide. Biol Blood Marrow Transplant (2008) 14(6):641-50. doi: 10.1016/j.bbmt.2008.03.005

5. Scandling JD, Busque S, Dejbakhsh-Jones S, Benike C, Millan MT, Shizuru JA, et al. Tolerance and Chimerism After Renal and Hematopoietic-Cell Transplantation. N Engl J Med (2008) 358(4):362-8. doi: 10.1056/ NEJMoa074191

6. Leventhal J, Abecassis M, Miller J, Gallon L, Ravindra K, Tollerud DJ, et al. Chimerism and Tolerance Without GVHD or Engraftment Syndrome in HLA-Mismatched Combined Kidney and Hematopoietic Stem Cell Transplantation. Sci Trans Med (2012) 4(124):124ra28. doi: 10.1126/ scitranslmed.3003509

7. Spence A, Klementowicz JE, Bluestone JA, Tang Q. Targeting Treg Signaling for the Treatment of Autoimmune Diseases. Curr Opin Immunol (2015) 37:11-20. doi: 10.1016/j.coi.2015.09.002

8. Abbas AK, Benoist C, Bluestone JA, Campbell DJ, Ghosh S, Hori S, et al. Regulatory T Cells: Recommendations to Simplify the Nomenclature. Nat Immunol (2013) 14(4):307-8. doi: 10.1038/ni.2554

9. Ferreira LMR, Muller YD, Bluestone JA, Tang Q. Next-Generation Regulatory T Cell Therapy. Nat Rev Drug Discov (2019) 18(10):749-69. doi: 10.1038/s41573-019-0041-4

10. Kwan T, Chadban SJ, Ma J, Bao S, Alexander SI, Wu H. IL-17 Deficiency Attenuates Allograft Injury and Prolongs Survival in a Murine Model of Fully MHC-Mismatched Renal Allograft Transplantation. Am J Transplant (2015) 15(6):1555-67. doi: 10.1111/ajt.13140

11. Hu M, Wang C, Zhang GY, Saito M, Wang YM, Fernandez MA, et al. Infiltrating Foxp3(+) Regulatory $\mathrm{T}$ Cells From Spontaneously Tolerant Kidney Allografts Demonstrate Donor-Specific Tolerance. Am J Transplant (2013) 13(11):2819-30. doi: 10.1111/ajt.12445

12. Wang YM, Zhang GY, Hu M, Polhill T, Sawyer A, Zhou JJ, et al. CD8+ Regulatory $\mathrm{T}$ Cells Induced by $\mathrm{T}$ Cell Vaccination Protect Against Autoimmune Nephritis. J Am Soc Nephrol (2012) 23(6):1058-67. doi: 10.1681/asn.2011090914

13. Wang YM, Zhang GY, Wang Y, Hu M, Wu H, Watson D, et al. Foxp3Transduced Polyclonal Regulatory T Cells Protect Against Chronic Renal Injury From Adriamycin. J Am Soc Nephrol (2006) 17(3):697-706. doi: $10.1681 /$ asn. 2005090978

14. Bluestone JA, Tang Q, Sedwick CE. T Regulatory Cells in Autoimmune Diabetes: Past Challenges, Future Prospects. J Clin Immunol (2008) 28 (6):677-84. doi: 10.1007/s10875-008-9242-z

15. Peters JH, Hilbrands LB, Koenen HJ, Joosten I. Ex Vivo Generation of Human Alloantigen-Specific Regulatory T Cells From CD4(pos)CD25(high) T Cells for Immunotherapy. PloS One (2008) 3(5):e2233. doi: 10.1371/ journal.pone.0002233

16. Zheng J, Liu Y, Qin G, Chan PL, Mao H, Lam KT, et al. Efficient Induction and Expansion of Human Alloantigen-Specific CD8 Regulatory T Cells of JDRF/Australian Research Council grant 4-SRA-2016265-M-B. SA is a chief investigator A of NHMRC Ideas Grant GNT1183810.

From Naive Precursors by CD40-Activated B Cells. J Immunol (Baltimore Md: 1950) (2009) 183(6):3742-50. doi: 10.4049/jimmunol.0901329

17. Kawai T, Leventhal J, Madsen JC, Strober S, Turka LA, Wood KJ. Tolerance: One Transplant for Life. Transplantation (2014) 98(2):117-21. doi: 10.1097/ tp. 0000000000000260

18. Sawitzki B, Harden PN, Reinke P, Moreau A, Hutchinson JA, Game DS, et al. Regulatory Cell Therapy in Kidney Transplantation (The ONE Study): A Harmonised Design and Analysis of Seven Non-Randomised, Single-Arm, Phase 1/2A Trials. Lancet (London England) (2020) 395(10237):1627-39. doi: 10.1016/s0140-6736(20)30167-7

19. Bluestone JA, Tang Q. T(reg) Cells-the Next Frontier of Cell Therapy. Sci (New York NY) (2018) 362(6411):154-5. doi: 10.1126/science.aau2688

20. Roemhild A, Otto NM, Moll G, Abou-El-Enein M, Kaiser D, Bold G, et al. Regulatory $\mathrm{T}$ Cells for Minimising Immune Suppression in Kidney Transplantation: Phase I/IIa Clinical Trial. BMJ (Clinical Res ed) (2020) 371:m3734. doi: 10.1136/bmj.m3734

21. Harden PN, Game DS, Sawitzki B, van der Net JB, Hester J, Bushell A, et al. Feasibility, Long-Term Safety, and Immune Monitoring of Regulatory T Cell Therapy in Living Donor Kidney Transplant Recipients. Am J Transplant (2021) 21(4):1603-11. doi: 10.1111/ajt.16395

22. Mathew JM, HV J, LeFever A, Konieczna I, Stratton C, He J, et al. A Phase I Clinical Trial With Ex Vivo Expanded Recipient Regulatory T Cells in Living Donor Kidney Transplants. Sci Rep (2018) 8(1):7428. doi: 10.1038/s41598018-25574-7

23. Mathew JM, Voss JH, McEwen ST, Konieczna I, Chakraborty A, Huang X, et al. Generation and Characterization of Alloantigen-Specific Regulatory T Cells For Clinical Transplant Tolerance. Sci Rep (2018) 8(1):1136. doi: 10.1038/s41598-018-19621-6

24. Hall BM, Jelbart ME, Gurley KE, Dorsch SE. Specific Unresponsiveness in Rats With Prolonged Cardiac Allograft Survival After Treatment With Cyclosporine. Mediation of Specific Suppression by T Helper/Inducer Cells. J Exp Med (1985) 162(5):1683-94. doi: 10.1084/jem.162.5.1683

25. Hall BM, Pearce NW, Gurley KE, Dorsch SE. Specific Unresponsiveness in Rats With Prolonged Cardiac Allograft Survival After Treatment With Cyclosporine. III. Further Characterization of the CD4+ Suppressor Cell and its Mechanisms of Action. J Exp Med (1990) 171(1):141-57. doi: $10.1084 /$ jem.171.1.141

26. Sakaguchi S, Sakaguchi N, Asano M, Itoh M, Toda M. Immunologic SelfTolerance Maintained by Activated T Cells Expressing IL-2 Receptor AlphaChains (CD25). Breakdown of a Single Mechanism of Self-Tolerance Causes Various Autoimmune Diseases. J Immunol (Baltimore Md: 1950) (1995) 155 (3):1151-64.

27. Hori S, Nomura T, Sakaguchi S. Control of Regulatory T Cell Development by the Transcription Factor Foxp3. Sci (New York NY) (2003) 299 (5609):1057-61. doi: 10.1126/science.1079490

28. Gratz IK, Rosenblum MD, Abbas AK. The Life of Regulatory T Cells. Ann New York Acad Sci (2013) 1283:8-12. doi: 10.1111/nyas.12011

29. Rossetti M, Spreafico R, Saidin S, Chua C, Moshref M, Leong JY, et al. Ex Vivo-Expanded But Not In Vitro-Induced Human Regulatory T Cells are Candidates for Cell Therapy in Autoimmune Diseases Thanks to Stable Demethylation of the FOXP3 Regulatory T Cell-Specific Demethylated Region. J Immunol (2015) 194(1):113-24. doi: 10.4049/jimmunol.1401145

30. Komatsu N, Okamoto K, Sawa S, Nakashima T, Oh-hora M, Kodama T, et al. Pathogenic Conversion of Foxp3+ T Cells Into TH17 Cells in Autoimmune Arthritis. Nat Med (2014) 20(1):62-8. doi: 10.1038/nm.3432

31. Verma ND, Plain KM, Nomura M, Tran GT, Robinson C, Boyd R, et al. CD4+CD25+ T Cells Alloactivated Ex Vivo by IL-2 or IL-4 Become Potent Alloantigen-Specific Inhibitors of Rejection With Different Phenotypes, Suggesting Separate Pathways of Activation by Th1 and Th2 Responses. Blood (2009) 113(2):479-87. doi: 10.1182/blood-2008-05-156612

32. Cretney E, Xin A, Shi W, Minnich M, Masson F, Miasari M, et al. The Transcription Factors Blimp-1 and IRF4 Jointly Control the Differentiation 
and Function of Effector Regulatory T Cells. Nat Immunol (2011) 12(4):30411. doi: $10.1038 /$ ni.2006

33. Rosenblum MD, Gratz IK, Paw IS, Lee K, Marshak-Rothstein A, Abbas AK. Response to Self Antigen Imprints Regulatory Memory in Tissues. Nature (2011) 480(7378):538-42. doi: 10.1038/nature10664

34. Hori S, Takahashi T, Sakaguchi S. Control of Autoimmunity by Naturally Arising Regulatory CD4+ T Cells. Adv Immunol (2003) 81:331-71. doi: 10.1016/s0065-2776(03)81008-8

35. Nicolson KS, O'Neill EJ, Sundstedt A, Streeter HB, Minaee S, Wraith DC. Antigen-Induced IL-10+ Regulatory T Cells Are Independent of CD25+ Regulatory Cells for Their Growth, Differentiation, and Function. J Immunol (Baltimore Md: 1950) (2006) 176(9):5329-37. doi: 10.4049/ jimmunol.176.9.5329

36. Rosenblum MD, Way SS, Abbas AK. Regulatory T Cell Memory. Nat Rev Immunol (2016) 16(2):90-101. doi: 10.1038/nri.2015.1

37. Lechler RI, Sykes M, Thomson AW, Turka LA. Organ Transplantation-How Much of the Promise has Been Realized? Nat Med (2005) 11(6):605-13. doi: $10.1038 / \mathrm{nm} 1251$

38. Russell PS, Chase CM, Colvin RB, Plate JM. Kidney Transplants in Mice. An Analysis of the Immune Status of Mice Bearing Long-Term, H-2 Incompatible Transplants. J Exp Med (1978) 147(5):1449-68. doi: 10.1084/ jem.147.5.1449

39. Wang C, Cordoba S, Hu M, Bertolino P, Bowen DG, Sharland AF, et al. Spontaneous Acceptance of Mouse Kidney Allografts is Associated With Increased Foxp3 Expression and Differences in the B and T Cell Compartments. Transplant Immunol (2011) 24(3):149-56. doi: 10.1016/ j.trim.2010.12.004

40. Bickerstaff AA, Wang JJ, Pelletier RP, Orosz CG. Murine Renal Allografts: Spontaneous Acceptance is Associated With Regulated T Cell-Mediated Immunity. J Immunol (Baltimore Md: 1950) (2001) 167(9):4821-7. doi: 10.4049/jimmunol.167.9.4821

41. Alexander SI, Smith N, Hu M, Verran D, Shun A, Dorney S, et al. Chimerism and Tolerance in a Recipient of a Deceased-Donor Liver Transplant. $N$ Engl J Med (2008) 358(4):369-74. doi: 10.1056/NEJMoa0707255

42. Miyajima M, Chase CM, Alessandrini A, Farkash EA, Della Pelle P, Benichou G, et al. Early Acceptance of Renal Allografts in Mice Is Dependent on Foxp3(+) Cells. Am J Pathol (2011) 178(4):1635-45. doi: 10.1016/j.aipath.2010.12.024

43. Quezada SA, Bennett K, Blazar BR, Rudensky AY, Sakaguchi S, Noelle RJ. Analysis of the Underlying Cellular Mechanisms of Anti-CD154-Induced Graft Tolerance: The Interplay of Clonal Anergy and Immune Regulation. J Immunol (Baltimore Md: 1950) (2005) 175(2):771-9. doi: 10.4049/ jimmunol.175.2.771

44. Bushell A, Karim M, Kingsley CI, Wood KJ. Pretransplant Blood Transfusion Without Additional Immunotherapy Generates CD25+CD4+ Regulatory T Cells: A Potential Explanation for the Blood-Transfusion Effect. Transplantation (2003) 76(3):449-55. doi: 10.1097/01.tp.0000083043.84630.99

45. Kishimoto K, Yuan X, Auchincloss HJr., Sharpe AH, Mandelbrot DA, Sayegh MH. Mechanism of Action of Donor-Specific Transfusion in Inducing Tolerance: Role of Donor MHC Molecules, Donor Co-Stimulatory Molecules, and Indirect Antigen Presentation. J Am Soc Nephrol (2004) 15(9):2423-8. doi: 10.1097/01.asn.0000137883.20961.2d

46. Lee K, Nguyen V, Lee KM, Kang SM, Tang Q. Attenuation of Donor-Reactive T Cells Allows Effective Control of Allograft Rejection Using Regulatory T Cell Therapy. Am J Transplant (2014) 14(1):27-38. doi: 10.1111/ajt.12509

47. Ochando JC, Homma C, Yang Y, Hidalgo A, Garin A, Tacke F, et al. Alloantigen-Presenting Plasmacytoid Dendritic Cells Mediate Tolerance to Vascularized Grafts. Nat Immunol (2006) 7(6):652-62. doi: 10.1038/ni1333

48. Sho M, Kishimoto K, Harada H, Livak M, Sanchez-Fueyo A, Yamada A, et al. Requirements for Induction and Maintenance of Peripheral Tolerance in Stringent Allograft Models. Proc Natl Acad Sci USA (2005) 102(37):13230-5. doi: 10.1073/pnas.0505070102

49. Young JS, Yin D, Vannier AGL, Alegre ML, Chong AS. Equal Expansion of Endogenous Transplant-Specific Regulatory T Cell and Recruitment Into the Allograft During Rejection and Tolerance. Front Immunol (2018) 9:1385. doi: 10.3389/fimmu.2018.01385

50. Kingsley CI, Karim M, Bushell AR, Wood KJ. CD25+CD4+ Regulatory T Cells Prevent Graft Rejection: CTLA-4- and IL-10-Dependent Immunoregulation of
Alloresponses. J Immunol (Baltimore Md: 1950) (2002) 168(3):1080-6. doi: 10.4049/jimmunol.168.3.1080

51. Burrell BE, Bromberg JS. Fates of CD4+ T Cells in a Tolerant Environment Depend on Timing and Place of Antigen Exposure. Am J Transplant (2012) 12(3):576-89. doi: 10.1111/j.1600-6143.2011.03879.x

52. Niimi M, Roelen DL, Witzke O, van Rood JJ, Claas FH, Wood KJ. The Importance of $\mathrm{H} 2$ Haplotype Sharing in the Induction of Specific Unresponsiveness by Pretransplant Blood Transfusions. Transplantation (2000) 69(3):411-7. doi: 10.1097/00007890-200002150-00018

53. Zhang GY, Hu M, Watson D, Wang YM, Knight JF, Alexander SI. Indirectly Activated Treg Allow Dominant Tolerance to Murine Skin-Grafts Across an MHC Class I Mismatch After a Single Donor-Specific Transfusion. Transplantation (2020) 104(7):1385-95. doi: 10.1097/tp.0000000000003173

54. Zuber J, Sykes M. Mechanisms of Mixed Chimerism-Based Transplant Tolerance. Trends Immunol (2017) 38(11):829-43. doi: 10.1016/j.it.2017.07.008

55. Kawai T, Sachs DH, Sykes M, Cosimi AB. HLA-Mismatched Renal Transplantation Without Maintenance Immunosuppression. $N$ Engl J Med (2013) 368(19):1850-2. doi: 10.1056/NEJMc1213779

56. Hu M, Kramer B, Zhang GY, Wang YM, Watson D, Howden B, et al. Methyl-Guanine-Methyl-Transferase Transgenic Bone Marrow Transplantation Allows N,N-Bis(2-Chloroethyl)-Nitrosourea Driven Donor Mixed-Chimerism Without Graft-VersusVersus-Host Disease, and With Donor-Specific Allograft Tolerance. Transplantation (2015) 99 (12):2476-84. doi: 10.1097/tp.0000000000000825

57. Joffre O, Santolaria T, Calise D, Al Saati T, Hudrisier D, Romagnoli P, et al. Prevention of Acute and Chronic Allograft Rejection With CD4+CD25 +Foxp3+ Regulatory T Lymphocytes. Nat Med (2008) 14(1):88-92. doi: $10.1038 / \mathrm{nm} 1688$

58. Bigenzahn S, Blaha P, Koporc Z, Pree I, Selzer E, Bergmeister H, et al. The Role of non-Deletional Tolerance Mechanisms in a Murine Model of Mixed Chimerism With Costimulation Blockade. Am J Transplant (2005) 5 (6):1237-47. doi: 10.1111/j.1600-6143.2005.00862.x

59. Koyama M, Kuns RD, Olver SD, Lineburg KE, Lor M, Teal BE, et al. Promoting Regulation via the Inhibition of DNAM-1 After Transplantation. Blood (2013) 121(17):3511-20. doi: 10.1182/blood-2012-07-444026

60. Pilat N, Wekerle T. Mechanistic and Therapeutic Role of Regulatory T Cells in Tolerance Through Mixed Chimerism. Curr Opin Organ Transplant (2010) 15(6):725-30. doi: 10.1097/MOT.0b013e3283401755

61. Savage TM, Shonts BA, Obradovic A, Dewolf S, Lau S, Zuber J, et al. Early Expansion of Donor-Specific Tregs in Tolerant Kidney Transplant Recipients. JCI Insight (2018) 3(22):e124086. doi: 10.1172/jci.insight.124086

62. Hotta K, Aoyama A, Oura T, Yamada Y, Tonsho M, Huh KH, et al. Induced Regulatory T Cells in Allograft Tolerance via Transient Mixed Chimerism. JCI Insight (2016) 1(10):e86419. doi: 10.1172/jci.insight.86419

63. Pathak S, Meyer EH. Tregs and Mixed Chimerism as Approaches for Tolerance Induction in Islet Transplantation. Front Immunol (2020) 11:612737. doi: 10.3389/fimmu.2020.612737

64. Pilat N, Granofszky N, Wekerle T. Combining Adoptive Treg Transfer With Bone Marrow Transplantation for Transplantation Tolerance. Curr Transplant Rep (2017) 4(4):253-61. doi: 10.1007/s40472-017-0164-7

65. Kinsella FAM, Zuo J, Inman CF, Pearce H, Maggs L, Eldershaw SE, et al. Mixed Chimerism Established by Hematopoietic Stem Cell Transplantation is Maintained by Host and Donor T Regulatory Cells. Blood Adv (2019) 3 (5):734-43. doi: 10.1182/bloodadvances.2018025502

66. Larsen CP, Elwood ET, Alexander DZ, Ritchie SC, Hendrix R, TuckerBurden C, et al. Long-Term Acceptance of Skin and Cardiac Allografts After Blocking CD40 and CD28 Pathways. Nature (1996) 381(6581):434-8. doi: $10.1038 / 381434 \mathrm{a} 0$

67. Taylor PA, Noelle RJ, Blazar BR. CD4(+)CD25(+) Immune Regulatory Cells are Required for Induction of Tolerance to Alloantigen via Costimulatory Blockade. J Exp Med (2001) 193(11):1311-8. doi: 10.1084/jem.193.11.1311

68. Wu J, Hu M, Qian YW, Hawthorne WJ, Burns H, Liuwantara D, et al. In Vivo Costimulation Blockade-Induced Regulatory T Cells Demonstrate Dominant and Specific Tolerance to Porcine Islet Xenografts. Transplantation (2017) 101(7):1587-99. doi: 10.1097/tp.0000000000001482

69. Choi HJ, Lee JJ, Kim DH, Kim MK, Lee HJ, Ko AY, et al. Blockade of CD40CD154 Costimulatory Pathway Promotes Long-Term Survival of FullThickness Porcine Corneal Grafts in Nonhuman Primates: Clinically 
Applicable Xenocorneal Transplantation. Am J Transplant (2015) 15 (3):628-41. doi: 10.1111/ajt.13057

70. Lehnert AM, Mottram PL, Han W, Walters SN, Patel AT, Hawthorne WJ, et al. Blockade of the CD28 and CD40 Pathways Result in the Acceptance of Pig and Rat Islet Xenografts But Not Rat Cardiac Grafts in Mice. Transplant Immunol (2001) 9(1):51-6. doi: 10.1016/s0966-3274(01)00040-5

71. Poirier N, Chevalier M, Mary C, Hervouet J, Minault D, Baker P, et al. Selective CD28 Antagonist Blunts Memory Immune Responses and Promotes Long-Term Control of Skin Inflammation in Nonhuman Primates. J Immunol (Baltimore Md: 1950) (2016) 196(1):274-83. doi: 10.4049/jimmunol.1501810

72. Tran HM, Nickerson PW, Restifo AC, Ivis-Woodward MA, Patel A, Allen $\mathrm{RD}$, et al. Distinct Mechanisms for the Induction and Maintenance of Allograft Tolerance With CTLA4-Fc Treatment. J Immunol (Baltimore Md: 1950) (1997) 159(5):2232-9.

73. Riella LV, Liu T, Yang J, Chock S, Shimizu T, Mfarrej B, et al. Deleterious Effect of CTLA4-Ig on a Treg-Dependent Transplant Model. Am J Transplant (2012) 12(4):846-55. doi: 10.1111/j.1600-6143.2011.03929.x

74. Adams AB, Ford ML, Larsen CP. Costimulation Blockade in Autoimmunity and Transplantation: The CD28 Pathway. J Immunol (Baltimore Md: 1950) (2016) 197(6):2045-50. doi: 10.4049/jimmunol.1601135

75. Charbonnier LM, Vokaer B, Lemaître PH, Field KA, Leo O, Le Moine A. CTLA4-Ig Restores Rejection of MHC Class-II Mismatched Allografts by Disabling IL-2-Expanded Regulatory T Cells. Am J Transplant (2012) 12 (9):2313-21. doi: 10.1111/j.1600-6143.2012.04184.x

76. Vogel I, Verbinnen B, Maes W, Boon L, Van Gool SW, Ceuppens JL. Foxp3+ Regulatory T Cells are Activated in Spite of B7-CD28 and CD40-CD40L Blockade. Eur J Immunol (2013) 43(4):1013-23. doi: 10.1002/eji.201242737

77. Jiang X, Sun W, Guo D, Cui Z, Zhu L, Lin L, et al. Cardiac Allograft Acceptance Induced by Blockade of CD40-CD40L Costimulation is Dependent on CD4+CD25+ Regulatory T Cells. Surgery (2011) 149 (3):336-46. doi: 10.1016/j.surg.2010.08.012

78. Graca L, Le Moine A, Lin CY, Fairchild PJ, Cobbold SP, Waldmann H. Donor-Specific Transplantation Tolerance: The Paradoxical Behavior of CD4+CD25+ T Cells. Proc Natl Acad Sci USA (2004) 101(27):10122-6. doi: $10.1073 /$ pnas. 0400084101

79. Tahvildari M, Dana R. Low-Dose IL-2 Therapy in Transplantation, Autoimmunity, and Inflammatory Diseases. I Immunol (Baltimore $\mathrm{Md}$ : 1950) (2019) 203(11):2749-55. doi: 10.4049/jimmunol.1900733

80. Abbas AK, Trotta E D, Marson A, Bluestone JA. Revisiting IL-2: Biology and Therapeutic Prospects. Sci Immunol (2018) 3(25):eaat1482. doi: 10.1126/ sciimmunol.aat 1482

81. Boyman O, Sprent J. The Role of Interleukin-2 During Homeostasis and Activation of the Immune System. Nat Rev Immunol (2012) 12(3):180-90. doi: $10.1038 /$ nri3156

82. Koreth J, Matsuoka K, Kim HT, McDonough SM, Bindra B, Alyea EP, et al. 3rdInterleukin-2 and Regulatory T Cells in Graft-Versus-Host Disease. New Engl J Med (2011) 365(22):2055-66. doi: 10.1056/NEJMoa1108188

83. Saadoun D, Rosenzwajg M, Joly F, Six A, Carrat F, Thibault V, et al. Regulatory T-Cell Responses to Low-Dose Interleukin-2 in HCV-Induced Vasculitis. N Engl J Med (2011) 365(22):2067-77. doi: 10.1056/ NEJMoa1 105143

84. He J, Zhang X, Wei Y, Sun X, Chen Y, Deng J, et al. Low-Dose Interleukin-2 Treatment Selectively Modulates CD4(+) T Cell Subsets in Patients With Systemic Lupus Erythematosus. Nat Med (2016) 22(9):991-3. doi: 10.1038/ nm. 4148

85. Rosenzwajg M, Churlaud G, Mallone R, Six A, Dérian N, Chaara W, et al. Low-Dose Interleukin-2 Fosters a Dose-Dependent Regulatory T Cell Tuned Milieu in T1D Patients. J Autoimmun (2015) 58:48-58. doi: 10.1016/ j.jaut.2015.01.001

86. Hartemann A, Bensimon G, Payan CA, Jacqueminet S, Bourron O, Nicolas $\mathrm{N}$, et al. Low-Dose Interleukin 2 in Patients With Type 1 Diabetes: A Phase 1/2 Randomised, Double-Blind, Placebo-Controlled Trial. Lancet Diabetes Endocrinol (2013) 1(4):295-305. doi: 10.1016/s2213-8587(13)70113-x

87. Yi S, Ji M, Wu J, Ma X, Phillips P, Hawthorne WJ, et al. Adoptive Transfer With In Vitro Expanded Human Regulatory T Cells Protects Against Porcine Islet Xenograft Rejection via Interleukin-10 in Humanized Mice. Diabetes (2012) 61(5):1180-91. doi: 10.2337/db11-1306
88. Tahvildari M, Omoto M, Chen Y, Emami-Naeini P, Inomata T, Dohlman $\mathrm{TH}$, et al. In Vivo Expansion of Regulatory $\mathrm{T}$ Cells by Low-Dose Interleukin-2 Treatment Increases Allograft Survival in Corneal Transplantation. Transplantation (2016) 100(3):525-32. doi: 10.1097/ tp.0000000000001044

89. Ratnasothy K, Jacob J, Tung S, Boardman D, Lechler RI, Sanchez-Fueyo A, et al. IL-2 Therapy Preferentially Expands Adoptively Transferred DonorSpecific Tregs Improving Skin Allograft Survival. Am J Transplant (2019) 19 (7):2092-100. doi: 10.1111/ajt.15306

90. Webster KE, Walters S, Kohler RE, Mrkvan T, Boyman O, Surh CD, et al. In Vivo Expansion of T Reg Cells With IL-2-mAb Complexes: Induction of Resistance to EAE and Long-Term Acceptance of Islet Allografts Without Immunosuppression. J Exp Med (2009) 206(4):751-60. doi: 10.1084/ jem.20082824

91. Polhill T, Zhang GY, Hu M, Sawyer A, Zhou JJ, Saito M, et al. IL-2/IL-2Ab Complexes Induce Regulatory $\mathrm{T}$ Cell Expansion and Protect Against Proteinuric CKD. J Am Soc Nephrol (2012) 23(8):1303-8. doi: 10.1681/ asn. 2011111130

92. Hu M, Hawthorne WJ, Nicholson L, Burns H, Qian YW, Liuwantara D, et al. Low-Dose Interleukin-2 Combined With Rapamycin Led to an Expansion of CD4(+)CD25(+)FOXP3(+) Regulatory T Cells and Prolonged Human Islet Allograft Survival in Humanized Mice. Diabetes (2020) 69(8):1735-48. doi: $10.2337 / \mathrm{db} 19-0525$

93. Hester J, Schiopu A, Nadig SN, Wood KJ. Low-Dose Rapamycin Treatment Increases the Ability of Human Regulatory T Cells to Inhibit Transplant Arteriosclerosis In Vivo. Am J Transplant (2012) 12(8):2008-16. doi: 10.1111/j.1600-6143.2012.04065.x

94. Battaglia M, Stabilini A, Roncarolo MG. Rapamycin Selectively Expands CD4+CD25+FoxP3+ Regulatory T Cells. Blood (2005) 105(12):4743-8. doi: 10.1182/blood-2004-10-3932

95. Wang Y, Camirand G, Lin Y, Froicu M, Deng S, Shlomchik WD, et al. Regulatory T Cells Require Mammalian Target of Rapamycin Signaling to Maintain Both Homeostasis and Alloantigen-Driven Proliferation in Lymphocyte-Replete Mice. J Immunol (Baltimore Md: 1950) (2011) 186 (5):2809-18. doi: 10.4049/jimmunol.0903805

96. Battaglia M, Stabilini A, Migliavacca B, Horejs-Hoeck J, Kaupper T, Roncarolo MG. Rapamycin Promotes Expansion of Functional CD4 +CD25+FOXP3+ Regulatory T Cells of Both Healthy Subjects and Type 1 Diabetic Patients. J Immunol (Baltimore Md: 1950) (2006) 177(12):8338-47. doi: 10.4049/jimmunol.177.12.8338

97. Pilon CB, Petillon S, Naserian S, Martin GH, Badoual C, Lang P, et al. Administration of Low Doses of IL-2 Combined to Rapamycin Promotes Allogeneic Skin Graft Survival in Mice. Am J Transplant (2014) 14 (12):2874-82. doi: 10.1111/ajt.12944

98. Tang Q, Henriksen KJ, Bi M, Finger EB, Szot G, Ye J, et al. In VitroExpanded Antigen-Specific Regulatory T Cells Suppress Autoimmune Diabetes. J Exp Med (2004) 199(11):1455-65. doi: 10.1084/jem.20040139

99. Masteller EL, Tang Q, Bluestone JA. Antigen-Specific Regulatory T Cells-Ex Vivo Expansion and Therapeutic Potential. Semin Immunol (2006) 18 (2):103-10. doi: 10.1016/j.smim.2006.01.004

100. Putnam AL, Safinia N, Medvec A, Laszkowska M, Wray M, Mintz MA, et al. Clinical Grade Manufacturing of Human Alloantigen-Reactive Regulatory T Cells for Use in Transplantation. Am J Transplant (2013) 13(11):3010-20. doi: 10.1111/ajt.12433

101. Sagoo P, Ali N, Garg G, Nestle FO, Lechler RI, Lombardi G. Human Regulatory T Cells With Alloantigen Specificity are More Potent Inhibitors of Alloimmune Skin Graft Damage Than Polyclonal Regulatory T Cells. Sci Trans Med (2011) 3(83):83ra42. doi: 10.1126/scitranslmed.3002076

102. Guinan EC, Cole GA, Wylie WH, Kelner RH, Janec KJ, Yuan H, et al. Ex Vivo Costimulatory Blockade to Generate Regulatory T Cells From Patients Awaiting Kidney Transplantation. Am J Transplant (2016) 16(7):2187-95. doi: $10.1111 /$ ajt. 13725

103. Tsang J, Jiang S, Tanriver Y, Leung E, Lombardi G, Lechler RI. In-Vitro Generation and Characterisation of Murine CD4+CD25+ Regulatory T Cells With Indirect Allospecificity. Int Immunopharmacol (2006) 6(13-14):18838. doi: 10.1016/j.intimp.2006.07.032

104. Weber EW, Maus MV, Mackall CL. The Emerging Landscape of Immune Cell Therapies. Cell (2020) 181(1):46-62. doi: 10.1016/j.cell.2020.03.001 
105. Simpson E, Scott D, Chandler P. The Male-Specific Histocompatibility Antigen, H-Y: A History of Transplantation, Immune Response Genes, Sex Determination and Expression Cloning. Annu Rev Immunol (1997) 15:39-61. doi: 10.1146/annurev.immunol.15.1.39

106. Chai JG, Coe D, Chen D, Simpson E, Dyson J, Scott D. In Vitro Expansion Improves In Vivo Regulation by CD4+CD25+ Regulatory T Cells. J Immunol (Baltimore Md: 1950) (2008) 180(2):858-69. doi: 10.4049/jimmunol.180.2.858

107. Verginis $\mathrm{P}, \mathrm{McLaughlin} \mathrm{KA}$, Wucherpfennig KW, von Boehmer H, Apostolou I. Induction of Antigen-Specific Regulatory T Cells in WildType Mice: Visualization and Targets of Suppression. Proc Natl Acad Sci USA (2008) 105(9):3479-84. doi: 10.1073/pnas.0800149105

108. Chai JG, James E, Dewchand H, Simpson E, Scott D. Transplantation Tolerance Induced by Intranasal Administration of HY Peptides. Blood (2004) 103(10):3951-9. doi: 10.1182/blood-2003-11-3763

109. Tsang JY, Tanriver Y, Jiang S, Xue SA, Ratnasothy K, Chen D, et al. Conferring Indirect Allospecificity on CD4+CD25+ Tregs by TCR Gene Transfer Favors Transplantation Tolerance in Mice. J Clin Invest (2008) 118 (11):3619-28. doi: 10.1172/jci33185

110. Dossa RG, Cunningham T, Sommermeyer D, Medina-Rodriguez I, Biernacki MA, Foster K, et al. Development of T-Cell Immunotherapy for Hematopoietic Stem Cell Transplantation Recipients at Risk of Leukemia Relapse. Blood (2018) 131(1):108-20. doi: 10.1182/blood-2017-07-791608

111. Boroughs AC, Larson RC, Choi BD, Bouffard AA, Riley LS, Schiferle E, et al. Chimeric Antigen Receptor Costimulation Domains Modulate Human Regulatory T Cell Function. JCI Insight (2019) 4(8):e126194. doi: 10.1172/ jci.insight. 126194

112. Kershaw MH, Westwood JA, Darcy PK. Gene-Engineered T Cells for Cancer Therapy. Nat Rev Cancer (2013) 13(8):525-41. doi: 10.1038/nrc3565

113. Hudecek M, Schmitt TM, Baskar S, Lupo-Stanghellini MT, Nishida T, Yamamoto TN, et al. The B-Cell Tumor-Associated Antigen ROR1 can be Targeted With T Cells Modified to Express a ROR1-Specific Chimeric Antigen Receptor. Blood (2010) 116(22):4532-41. doi: 10.1182/blood2010-05-283309

114. June CH, Sadelain M. Chimeric Antigen Receptor Therapy. New Engl J Med (2018) 379(1):64-73. doi: 10.1056/NEJMra1706169

115. Mehta RS, Rezvani K. Chimeric Antigen Receptor Expressing Natural Killer Cells for the Immunotherapy of Cancer. Front Immunol (2018) 9:283. doi: 10.3389/fimmu.2018.00283

116. MacDonald KG, Hoeppli RE, Huang Q, Gillies J, Luciani DS, Orban PC, et al. Alloantigen-Specific Regulatory T Cells Generated With a Chimeric Antigen Receptor. J Clin Invest (2016) 126(4):1413-24. doi: 10.1172/jci82771

117. Noyan F, Zimmermann K, Hardtke-Wolenski M, Knoefel A, Schulde E, Geffers R, et al. Prevention of Allograft Rejection by Use of Regulatory T Cells With an MHC-Specific Chimeric Antigen Receptor. Am J Transplant (2017) 17(4):917-30. doi: 10.1111/ajt.14175

118. Boardman DA, Philippeos C, Fruhwirth GO, Ibrahim MA, Hannen RF, Cooper D, et al. Expression of a Chimeric Antigen Receptor Specific for Donor HLA Class I Enhances the Potency of Human Regulatory T Cells in Preventing Human Skin Transplant Rejection. Am J Transplant (2017) 17 (4):931-43. doi: 10.1111/ajt.14185

119. Sicard A, Lamarche C, Speck M, Wong M, Rosado-Sánchez I, Blois M, et al. Donor-Specific Chimeric Antigen Receptor Tregs Limit Rejection in Naive But Not Sensitized Allograft Recipients. Am J Transplant (2020) 20(6):156273. doi: $10.1111 /$ ajt.15787

120. Rosado-Sánchez I, Levings MK. Building a CAR-Treg: Going From the Basic to the Luxury Model. Cell Immunol (2020) 358:104220. doi: 10.1016/ j.cellimm.2020.104220
121. Schmidt A, Eriksson M, Shang MM, Weyd H, Tegnér J. Comparative Analysis of Protocols to Induce Human CD4+Foxp3+ Regulatory T Cells by Combinations of IL-2, TGF-Beta, Retinoic Acid, Rapamycin and Butyrate. PloS One (2016) 11(2):e0148474. doi: 10.1371/journal.pone.0148474

122. Alvarez-Salazar EK, Cortés-Hernández A, Arteaga-Cruz S, Alberú-Gómez J, Soldevila G. Large-Scale Generation of Human Allospecific Induced Tregs With Functional Stability for Use in Immunotherapy in Transplantation. Front Immunol (2020) 11:375. doi: 10.3389/fimmu.2020.00375

123. Roncarolo MG, Gregori S, Bacchetta R, Battaglia M, Gagliani N. The Biology of T Regulatory Type 1 Cells and Their Therapeutic Application in ImmuneMediated Diseases. Immunity (2018) 49(6):1004-19. doi: 10.1016/ j.immuni.2018.12.001

124. Mfarrej B, Tresoldi E, Stabilini A, Paganelli A, Caldara R, Secchi A, et al. Generation of Donor-Specific Trl Cells to be Used After Kidney Transplantation and Definition of the Timing of Their In Vivo Infusion in the Presence of Immunosuppression. J Trans Med (2017) 15(1):40. doi: 10.1186/s12967-017-1133-8

125. MacDonald KN, Piret JM, Levings MK. Methods to Manufacture Regulatory T Cells for Cell Therapy. Clin Exp Immunol (2019) 197(1):52-63. doi: 10.1111/cei.13297

126. Trzonkowski P, Zilvetti M, Friend P, Wood KJ. Recipient Memory-Like Lymphocytes Remain Unresponsive to Graft Antigens After CAMPATH-1H Induction With Reduced Maintenance Immunosuppression. Transplantation (2006) 82(10):1342-51. doi: 10.1097/01.tp.0000239268.64408.84

127. Chandran S, Tang Q, Sarwal M, Laszik ZG, Putnam AL, Lee K, et al. Polyclonal Regulatory T Cell Therapy for Control of Inflammation in Kidney Transplants. Am J Transplant (2017) 17(11):2945-54. doi: 10.1111/ajt.14415

128. Safinia N, Vaikunthanathan T, Fraser H, Thirkell S, Lowe K, Blackmore L, et al. Successful Expansion of Functional and Stable Regulatory T Cells for Immunotherapy in Liver Transplantation. Oncotarget (2016) 7(7):7563-77. doi: 10.18632/oncotarget.6927

129. Canavan JB, Scottà C, Vossenkämper A, Goldberg R, Elder MJ, Shoval I, et al. Developing In Vitro Expanded CD45RA+ Regulatory T Cells as an Adoptive Cell Therapy for Crohn's Disease. Gut (2016) 65(4):584-94. doi: 10.1136/ gutjnl-2014-306919

130. Koyama I, Bashuda H, Uchida K, Seino KI, Habu S, Nakajima I, et al. A Clinical Trial With Adoptive Transfer of Ex Vivo-Induced, Donor-Specific ImmuneRegulatory Cells in Kidney Transplantation-A Second Report. Transplantation (2020) 104(11):2415-23. doi: 10.1097/tp.0000000000003149

Conflict of Interest: The authors declare that the research was conducted in the absence of any commercial or financial relationships that could be construed as a potential conflict of interest.

Publisher's Note: All claims expressed in this article are solely those of the authors and do not necessarily represent those of their affiliated organizations, or those of the publisher, the editors and the reviewers. Any product that may be evaluated in this article, or claim that may be made by its manufacturer, is not guaranteed or endorsed by the publisher.

Copyright (๑) $2021 \mathrm{Hu}$, Rogers, Li, Zhang, Wang, Shaw, O'Connell and Alexander. This is an open-access article distributed under the terms of the Creative Commons Attribution License (CC BY). The use, distribution or reproduction in other forums is permitted, provided the original author(s) and the copyright owner(s) are credited and that the original publication in this journal is cited, in accordance with accepted academic practice. No use, distribution or reproduction is permitted which does not comply with these terms. 